\title{
Direct Medical Costs Related To Clinical Outcomes And Patterns Of Ischemic Stroke Drug Therapy In Panti Rapih Hospital Yogyakarta
}

\author{
Muslimah $^{1 *}$, Nina Anggraeni Noviasari ${ }^{2}$, Nandhini Lawrence Anantaizaldy ${ }^{3}$ \\ ${ }^{1,2}$ Faculty of Medicine, Universitas Muhammadiyah Semarang \\ ${ }^{3}$ Student of Faculty of Medicine, Universitas Muhammadiyah Semarang \\ ${ }^{*}$ Corresponding author \\ Email: muslimah@unimus.ac.id
}

\begin{abstract}
This study aimed to analyze clinical outcomes related to direct medical cost and the pattern of drug therapy. This was an analytical observational study with retrospective and concurrent data through observation from the perspective of the hospital. A total of 42 stroke ischaemic patients were enrolled in this study. Data were collected with a period of 1 year after the first stroke occurrence, which began on May 15th, 2019 until June 15th, 2020. Data sources used in this study include medical records, financial data, and drug data from pharmacies. Data were analyzed using the Mann-Whitney $U$ test and the Kruskal-Wallis test. This study findings showed the highest sociodemographic data on age 41-70 years $(54,76 \%)$, male $(59,52 \%)$, length of stay of 5-10 days $(66,60 \%)$, comorbid of hypertension $(88,10 \%)$, complication of urinary tract infection $(19,05 \%)$, CCI 3-5 $(85,71 \%)$, condition at hospital admission of hemiparesis (83,72\%), and Antiplatelet drug therapy $(90,48 \%)$. Clinical outcomes of disability mostly occurred in males $(59,52 \%)$, age $41-70$ years $(54,76 \%)$, and length of stay of 5-10 days $(66,67 \%)$. There were 48 events of clinical outcome including $14,29 \%$ recurrent stroke and disability $(n=6), 100 \%$ disability $(n=42)$ and no mortality $(n=0)$. Recurrent stroke and disability were not associated with a direct medical cost per year, neither inpatient nor outpatient cost. This might be due to the severity of stroke at the hospital admission which not be considered in this study. In conclusion, this study's findings could be used as consideration in the determination of health policy, health insurance, and data source for pharmacoeconomic.
\end{abstract}

Keywords: Stroke; Clinical outcome; Drug; Cost.

\section{INTRODUCTION}

The main goals of comprehensive stroke management are: (1) to minimize the number of damaged cells through tissue repair and prevention of further bleeding in intracerebral hemorrhage, (2) to prevent early medical complications, and (3) to accelerate neurological function recovery. overall. If the overall stroke management is successful, the patient is expected to have a better prognosis [1].Stroke is the third most common cause of death after heart disease and cancer and ranks first as a cause of disability [2]. Stroke patients often require further treatment and long-term rehabilitation. According to the American Heart Association's policy statement, the cost of stroke treatment will more than double by 2030, and the incidence of stroke will increase in Americans aged 45-64 years. This increase occurred for several reasons including the cost of stroke management in the US which increased in 2010 from $\$ 71.55$ billion to $\$ 183.13$ billion, the cost of lost productivity increased by 33.65 billion dollars to $\$ 56.54$ billion annually, the increase in the prevalence of stroke in the US population by $5.1 \%$ [3]. Stroke also has the highest mortality rate in Indonesia according to Riskesdas 2013. Treatment of stroke due to disability and recurrent stroke requires a fairly high cost to deal with these conditions. In 2007, the average total treatment cost for ischemic stroke was $\mathrm{Rp}$ 4,340,000 and Rp 5,300,000 for hemorrhagic stroke at Sardjito Hospital, Yogyakarta.

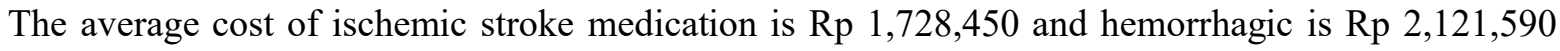
[4].Clinical outcome is the result of therapy, which is the goal of therapeutic services, to improve or achieve 
a better quality of life for patients [5]. Most of which can be observed from the data of several hospitals. Stroke prognosis can be seen from six aspects, including death, disease, disability, discomfort, dissatisfaction, and destitution. The six aspects of the prognosis occur in the early phase of stroke or after stroke. To prevent this aspect from getting worse, all patients with acute stroke must be carefully monitored for their general condition, brain function, ECG, oxygen saturation, blood pressure, and body temperature continuously for 24 hours after a stroke [6].Cost of Illness analysis measures the economic burden of disease and estimates the maximum potential amount that could be saved or saved if the disease could be prevented. Many Cost of Illness studies has been conducted over the last 30 years [7]. The important role of Cost of Illness studies can be seen from the frequent use by policymakers of the National Health Insurance Program (JKN). Most of these studies have played a role in public health policy debates because they highlight the magnitude of the impact of disease on society [8].

The goals of stroke therapy are to reduce ongoing neurological injury and reduce mortality and longterm disability, prevent secondary complications to immobility and neurological dysfunction, and prevent recurrent stroke [9]. Pharmacological therapy for ischemic stroke is to remove blockages in blood flow by using drugs. There are two specific treatment principles, namely treatment to restore brain circulation in the area affected by stroke and action to restore circulation and perfusion of brain tissue called reperfusion/thrombolytic therapy. And for specific purposes, drugs that can destroy emboli or thrombus in blood vessels are used [10]. Therapies carried out include: supportive therapy, antiplatelet therapy, anticoagulant therapy, neuroprotection therapy. Pharmacological therapy and management of acute stroke therapy are carried out to obtain maximum clinical outcomes, including (1) reducing the progression of neurological damage and reducing mortality, (2) preventing secondary complications, namely neurological dysfunction and permanent immobility, (3) preventing stroke recurrence. The therapy given depends on the type of stroke (ischemic or hemorrhagic) and based on the period of therapy (therapy in the acute phase and secondary preventive therapy or rehabilitation) [11].This study is different from other studies because, in addition to describing the clinical outcome of ischemic stroke, it is also associated with direct medical costs and the pattern of drug therapy in ischemic stroke patients.

\section{METHODS}

The study was conducted with an analytic observational design, the data were taken retrospectively and concurrently by conducting field observations to obtain research data from the perspective of the hospital. The research subjects were ischemic stroke patients totaling 42 patients. The period of study was carried out for a period of 1 year after the patient had a stroke for the first time on May 15th, 2019 - June 15th, 2020. The data sources used were medical records, financial data, drug data from the pharmacy. Statistical analysis of the relationship between clinical outcomes and direct medical costs based on patient characteristics variables was performed by Mann-Whitney analysis for 2 groups and Kruskal-Wallis analysis for more than 2 groups. The research stages of preparation for the literature study were continued by collecting direct medical cost data and drug data. The next stage is the clinical outcome data taken from the patient's medical record which includes the incidence of death, disability, and recurrence in the patient within one year since the patient was hospitalized for the first time. Subsequent data collection includes diagnosis, accompanying comorbidities, complications, results of laboratory tests, and description of drug use.

Single sample for estimating the proportion of clinical outcome population:

$\mathrm{n}=$ Number of samples needed

$$
\begin{aligned}
& n=\frac{(\mathrm{Z} \alpha)^{2} \mathrm{P} Q}{d^{2}} \\
& n=\frac{(1,96)^{2} 0,025(1-0,025)}{0,05^{2}} \\
& n=37,46+10 \% 37,46 \\
& n=41,20=41
\end{aligned}
$$

$\alpha=$ tolerable error (type I error) $=5 \%, 95 \% \mathrm{CI}$, so $(\mathrm{Z} \alpha)=1.96$ 
$\mathrm{P}=$ Percentage proportion of onset less than 24 hours in a year in the group whose value is known $=0.025$ (Williams et al., 2009)

$\mathrm{d}=$ The desired absolute level of accuracy is $5 \%$

$\mathrm{Q}=$ Proportion of remainder in population $(1-\mathrm{P})=(1-0.025)$

The minimum number of samples required is 41 patients. The sample according to the formula is 41 patients who meet the inclusion criteria and are listed in the stroke register at Panti Rapih Hospital, Yogyakarta.The research materials used in this study were patient medical record data; details of the real costs of stroke patients and Pharmacy data from the Pharmacy Department. Descriptive analysis was conducted to describe the total cost of stroke, the cost components included in the total cost of stroke. Analysis of the cost difference for stroke patients at Panti Rapih Hospital in terms of age, gender, class of treatment, length of stay, and the number of comorbidities was performed using Mann-Whitney $U$ test for a two-group difference test, and Kruskal-Wallis for a different test of more than 2 groups with $95 \%$ confidence interval $(\alpha=5 \%)[12]$.

\section{RESULTS AND DISCUSSION}

\section{Subject's sociodemographic characteristics}

Sociodemographic data of the patients were collected including patient characteristics based on age, gender and characteristics of the length of stay, comorbidities, complications, Charlson Comorbidity Index (CCI), conditions at hospital admission, and pharmacological therapy.Table I presented the frequency of patients based on the characteristics. The results showed that patients were mostly $41-70$ years old (54.76\%). This finding was in accordance with the research of İçağasioğlu et al. (2017) in Turkey, that the older the age, the higher the comorbidity and the severity of stroke so that the incidence of stroke also increases, and also similar with the study by Jennum et al. (2015) who reported that ischemic stroke was mostly experienced by patients aged 40-69 years (38.80\%). According to research in Malaysia in 2012, the main factor influencing the cost of stroke is age [13]. Research in Singapore stated that age affects the real cost of stroke. In addition, the length of treatment also had a significant influence on the cost of treating ischemic stroke patients in hospitals [14].Male was more prone to stroke; this is due to the higher incidence of stroke risk factors in the form of hypertension in males [15]. Stroke patients were dominated by men with an age range of 46 to 55 years. This was in accordance with the study of hypertension as the biggest risk factor for stroke in men [16]. Strokes were more common in men. Stroke in women was lower than in men, due to the presence of estrogen which functions as protection in the atherosclerosis process [17].The longest length of stay in this study was 5-10 days (66.67\%). The average length of stay for non-hemorrhagic stroke patients in Europe and America was 10.5 days, including the length of treatment for medical rehabilitation and nursing home. The disease severity factor also determined the LOS, the more severe the disease, the longer the day of hospitalization was required [18].

The average LOS from the study at the Sragen Hospital was recorded at \pm 10 days and the patients who underwent treatment were elderly patients who had a higher number of secondary diagnoses such as hypertension, chronic ischemic heart disease, and diabetes mellitus [19]. This study's finding showed that hypertension was the most common secondary diagnosis accompanying stroke for all diagnostic codes (88.10\%). This was in accordance with research which shows that hypertension is a diagnosis of stroke for all diagnostic codes and most commonly occurs in ischemic stroke because hypertension can cause narrowing or rupture of blood vessels in the brain and if the blood vessels in the brain are narrowed, blood flow to the brain will be disrupted and finally leading to brain cells death [20]. High blood pressure (systolic blood pressure $>140 \mathrm{mmHg}$ and diastolic blood pressure $90 \mathrm{mmHg}$ ) will increase the risk of recurrent stroke [21].Table I showed that the biggest complication of ischemic stroke was urinary tract infection (19.05\%). In accordance with a study in China which stated that a complication that often occurs in stroke patients was urinary tract infection (UTI) which could worsen the patient's clinical outcome and result in an extension of the length of stay of stroke patients [22]. The direct result of this prolonged length of hospitalization would also increase the cost of treatment of stroke patients. Study-related to infection and clinical outcomes of stroke is still limited in Indonesia. UTIs increase inflammation in the arteries which can contribute to blood 
clots and blood clot formation, blocking blood flow and oxygen supply to the brain, leading to an ischemic stroke. The scientists found that patients with UTIs were three times more likely to have an ischemic stroke within 30 days of being infected [23].

Table 1. Sociodemographic of inpatient's ischemic stroke patients $(n=42)$

\begin{tabular}{|c|c|c|}
\hline Variables & $\mathrm{n}=42$ & $\%$ \\
\hline \multicolumn{3}{|l|}{ Subject's characteristics } \\
\hline \multicolumn{3}{|l|}{ Age (years) } \\
\hline$<41$ & 0 & $0,00 \%$ \\
\hline $41-70$ & 23 & $54,76 \%$ \\
\hline$>70$ & 19 & $45,24 \%$ \\
\hline \multicolumn{3}{|l|}{ Sex } \\
\hline Male & 25 & $59,52 \%$ \\
\hline Female & 17 & $40,48 \%$ \\
\hline \multicolumn{3}{|l|}{ Clinical characteristics } \\
\hline \multicolumn{3}{|l|}{ Length of stay (days) } \\
\hline$<5$ & 9 & $21,43 \%$ \\
\hline $5-10$ & 28 & $66,67 \%$ \\
\hline $11-15$ & 5 & $11,90 \%$ \\
\hline \multicolumn{3}{|l|}{ Comorbid } \\
\hline Diabetes Mellitus & 14 & $33,33 \%$ \\
\hline Heart disease & 3 & $7,14 \%$ \\
\hline Hypertension & 37 & $88,10 \%$ \\
\hline Dyslipidaemia & 7 & $16,67 \%$ \\
\hline \multicolumn{3}{|l|}{ Complication } \\
\hline Urinary tract infection & 8 & $19,05 \%$ \\
\hline Anorexia & 1 & $2,38 \%$ \\
\hline \multicolumn{3}{|l|}{ Charlson Comorbidity Index } \\
\hline $0-2$ & 6 & $14,29 \%$ \\
\hline $3-5$ & 36 & $85,71 \%$ \\
\hline \multicolumn{3}{|l|}{ Condition at hospital admission } \\
\hline Hemiparesis & 36 & $83,72 \%$ \\
\hline Communication difficulties & 20 & $46,51 \%$ \\
\hline Facial deviation & 3 & $6,98 \%$ \\
\hline Loss of consciousness & 5 & $11,63 \%$ \\
\hline Swallowing difficulty & 3 & $6,98 \%$ \\
\hline \multicolumn{3}{|l|}{ Pharmacological therapy } \\
\hline Antiplatelet & 40 & $95,24 \%$ \\
\hline Antihypertensive & 30 & $71,43 \%$ \\
\hline Neuroprotective & 9 & $21,43 \%$ \\
\hline Antihyperlipidemic & 5 & $11,90 \%$ \\
\hline Anticoagulant & 38 & $90,48 \%$ \\
\hline
\end{tabular}

Source: medical record secondary data processing

Charlson Comorbidity Index (CCI) or Charlson Index Score (CIS) describes the severity of comorbidities. Table I showed most of the patients had CCI 3-5, which was as much as $85.71 \%$. CCI components include age, heart disease, diabetes mellitus, condition of the patient at the time of hospital admission, and other comorbidities [24]. CIS was calculated based on the Charlson Comorbidity Index (Charlson et al., 1987) and CCI scores were grouped into four namely CCI scores 0-2, CCI 3-5, CCI 6-8, and CCI 9-11. Comorbidity data were recorded according to the data written on the status, then scored according to the CCI.The condition when admitted to the hospital was mostly $(83.72 \%)$ in the form of paralysis of the limbs (hemiparesis).

Approximately $25-40 \%$ of stroke patients will suffer from aphasia. Aphasia is not a disease, but rather a symptom that indicates damage to the part of the brain that regulates language and communication. One of the most common causes of brain damage that triggers aphasia is stroke. When you have a stroke, the lack of blood flow to the brain causes brain cell death or damage to the part of the brain that processes language [25].Antiplatelet pharmacological therapy was the most widely administered therapy (95.91\%). Antiplatelet drugs are drugs that can inhibit platelet aggregation, causing inhibition of thrombus formation, which is especially often found in the arterial system [9]. Antiplatelet use is important for acute ischemic 
stroke. Giving antiplatelet therapy can reduce the incidence of recurrent stroke from $68 \%$ to $24 \%$ [26]. The goal of antiplatelet therapy is to prevent platelet aggregation in ischemic stroke patients [27].

\section{Laboratory parameter of ischemic stroke patients}

A total of $76.19 \%$ of patients had normal blood sugar levels $(<200 \mathrm{mg} / \mathrm{dL})$ and $23.81 \%$ had blood sugar levels of $>200 \mathrm{mg} / \mathrm{dL}$. Research from Rico Januar et al. (2010) stated that the risk factors that were independently associated with the incidence of stroke at a young age were gender, heart disorder, blood sugar levels, fasting blood sugar levels, blood sugar levels 2 hours PP, total blood cholesterol, and total triglycerides.

Table 2. Laboratory parameters of hospitalized ischemic stroke patients on admission to the hospital $(n=42)$

\begin{tabular}{|c|c|c|c|c|}
\hline Laboratory parameters & & value & $\mathrm{n}=42$ & $\%$ \\
\hline \multirow{4}{*}{$\begin{array}{l}\text { Classification of hypertension } \\
\text { according to International Society } \\
\text { of Hypertension }{ }^{31}\end{array}$} & Normal & $<130 /<85$ & 5 & $11,90 \%$ \\
\hline & High normal & $130-139 / 85-89$ & 3 & $7,14 \%$ \\
\hline & HT stage 1 & $140-159 / 90-99$ & 10 & $23,81 \%$ \\
\hline & HT stage 2 & $\geq 160 / \geq 100$ & 24 & $57,14 \%$ \\
\hline \multirow{2}{*}{ Blood sugar (mg/dL) } & Normal & $<200$ & 32 & $76,19 \%$ \\
\hline & High & $\geq 200$ & 10 & $23,81 \%$ \\
\hline \multirow{3}{*}{$\begin{array}{l}\text { Total Cholesterol }(\mathrm{mg} / \mathrm{dL}) \\
\text { according to the Guideline of } \\
\text { Dyslipidaemia Management in } \\
\text { Indonesia } 2019^{32}\end{array}$} & Normal & $<200$ & 34 & $80,95 \%$ \\
\hline & High normal & $200-239$ & 5 & $11,90 \%$ \\
\hline & High & $\geq 240$ & 3 & $7,14 \%$ \\
\hline \multirow{3}{*}{ Total Triglycerides $(\mathrm{mg} / \mathrm{dL})$} & Normal & $<200$ & 33 & $78,57 \%$ \\
\hline & High normal & $200-240$ & 5 & $11,90 \%$ \\
\hline & High & $>240$ & 4 & $9,52 \%$ \\
\hline \multirow{4}{*}{ Pain scale } & No pain (unconscious) & '0 & 30 & $71,43 \%$ \\
\hline & Mild & ' $1-3$ & 8 & $19,05 \%$ \\
\hline & Moderate & '4-6 & 3 & $7,14 \%$ \\
\hline & Severe & $77-10$ & 1 & $2,38 \%$ \\
\hline
\end{tabular}

Source: medical record secondary data processing

This study was in line with the study conducted by Husni and Laksmawati, (2001) which stated that there was not a strong relationship between hypercholesterolemia and the incidence of stroke directly. Patients with hypercholesterolemia would experience coronary heart disease earlier than stroke [29]. A metaanalysis study conducted on 460,000 stroke patients showed that there was no significant relationship between the incidence of stroke with serum cholesterol and blood triglycerides [30].

\section{Overview of Ischemic Stroke Treatment}

In general, the goals of stroke therapy are to reduce ongoing neurological injury, reduce mortality and long-term disability, prevent secondary complications, and prevent recurrence of stroke [33]. In ischemic stroke, the goals of therapy are to maintain normal blood pressure and improve blood flow by preventing clots [34].Table III showed the description of treatment in ischemic stroke patients. The most used treatment was the antiplatelet clopidogrel (53.54\%). Antiplatelet use is recommended to reduce the incidence of recurrent stroke and other cardiovascular events [35]. Neuroprotective use is intended to delay the occurrence of infarction in ischemic brain regions, especially the penumbra, and not to repair reperfusion to tissues [36].

Antiplatelet therapy is the most widely used therapy in the treatment of ischemic stroke, both inpatient and outpatient, mostly using antiplatelet cyclooxygenase (COX) inhibitors (aspirin) as much as $77.06 \%$, followed by the $\mathrm{P}_{2} \mathrm{Y}_{12}$ receptor blocker (clopidogrel) drug class as much as $47.82 \%$ and the phosphodiesterase inhibitors (Cilostazol) class of drugs was $7.11 \%$. In general, only two drugs are recommended for grade A ischemic stroke, namely tissue Plasminogen Activator given in the first 4.5 hours of attack and aspirin at 48 hours after onset. The goals of stroke therapy are to maintain normal blood pressure and improve blood flow by preventing clots from occurring again. This can be done by administering antihypertensives, antiplatelets, or anticoagulants [11]. In ischemic stroke patients, the use of antiplatelets is recommended to reduce the incidence of recurrent stroke and other cardiovascular events [35].Another antiplatelet therapy used was clopidogrel which was used by $47.82 \%$ of patients. The use of 
clopidogrel alone is an option for patients who are allergic to aspirin and can replace aspirin or a combination of aspirin and dipyridamole for secondary prevention of stroke [37].

Table 3. Pharmacology therapy pattern of ischemic stroke patients $(n=42)$

\begin{tabular}{|c|c|c|c|c|c|c|}
\hline Therapy classification & $\begin{array}{c}\text { Pharmacology } \\
\text { classification }\end{array}$ & Drug & $\begin{array}{l}\text { Code } \\
\text { ATC }\end{array}$ & $\mathbf{n}$ & $\begin{array}{c}n \\
\text { total }\end{array}$ & $\begin{array}{c}\text { Percentage } \\
(\%)\end{array}$ \\
\hline \multicolumn{7}{|l|}{ Antiplatelet $(\mathrm{N}=94)$} \\
\hline \multirow{3}{*}{$\underline{\text { Antithrombotic Agents }}$} & \multirow{3}{*}{$\frac{\text { Antithrombotic }}{\underline{\text { Agents }}}$} & Aspirin & B01AC06 & 38 & 38 & $38,38 \%$ \\
\hline & & Clopidogrel & $\mathrm{B} 01 \mathrm{AC} 04$ & 53 & 53 & $53,54 \%$ \\
\hline & & Cilostazol & $\mathrm{B} 01 \mathrm{AC} 23$ & 5 & 5 & $5,05 \%$ \\
\hline \multicolumn{7}{|l|}{ Anticoagulant $(\mathrm{N}=\mathbf{2 0})$} \\
\hline \multirow{2}{*}{ Antithrombotic Agents } & \multirow{2}{*}{$\underline{\text { Antithrombotic }}$} & Rivaroxaban & B01AF01 & 0 & 0 & $0,00 \%$ \\
\hline & & Warfarin & B01AA03 & 2 & 2 & $2,02 \%$ \\
\hline \multicolumn{7}{|c|}{ Statins/Antihyperlipidemia $(\mathrm{N}=174)$} \\
\hline \multirow{5}{*}{$\frac{\text { Lipid Modifving }}{\underline{\text { Agents }}}$} & \multirow{5}{*}{$\begin{array}{l}\text { Lipid Modifying } \\
\underline{\text { Agents, Plain }}\end{array}$} & Gemfibrozil & C10AB04 & 0 & 0 & $0,00 \%$ \\
\hline & & Fenofibrate & C10AB05 & 0 & 0 & $0,00 \%$ \\
\hline & & Simvastatin & C10AA01 & 5 & 5 & $5,05 \%$ \\
\hline & & Atorvastatin & C10AA05 & 2 & 2 & $2,02 \%$ \\
\hline & & Pravastatin & C10AA03 & 0 & 0 & $0,00 \%$ \\
\hline \multicolumn{7}{|l|}{ Neuroprotective $(\mathbf{N}=337)$} \\
\hline \multirow[b]{2}{*}{ Psychoanaleptics } & \multirow{2}{*}{$\begin{array}{l}\text { Other } \\
\text { Psychostimulants And } \\
\text { Nootropics }\end{array}$} & Citicoline & N06BX06 & 0 & 0 & $0,00 \%$ \\
\hline & & Piracetam & N06BX03 & 0 & 0 & $0,00 \%$ \\
\hline $\begin{array}{l}\text { Other Diagnostic } \\
\text { Agents }\end{array}$ & $\begin{array}{l}\text { Other Diagnostic } \\
\text { Agents }\end{array}$ & Folic Acid & V04CX02 & 0 & 0 & $0,00 \%$ \\
\hline $\begin{array}{l}\text { Antianemic } \\
\text { Preparations } \\
\end{array}$ & $\begin{array}{l}\text { Vitamin B12 and } \\
\text { Folic Acid }\end{array}$ & Mecobalamin & B03BA05 & 9 & 9 & $9,09 \%$ \\
\hline \multicolumn{7}{|c|}{ Antihypertensive $(\mathrm{N}=\mathbf{4 1 0})$} \\
\hline \multirow[t]{4}{*}{$\begin{array}{l}\text { Agents Acting On The } \\
\text { Renin-Angiotensin } \\
\text { System }\end{array}$} & $\begin{array}{l}\text { Angiotensin } \\
\text { Converter Enzyme } \\
(A C E) \text { Inhibitor }\end{array}$ & Captopril & C09AA01 & 0 & 0 & $0,00 \%$ \\
\hline & & Lisinopril & C09AA03 & 0 & 0 & $0,00 \%$ \\
\hline & $\begin{array}{l}\text { Angiotensin Ii } \\
\text { Receptor Blockers } \\
\text { (ARBS), Plain }\end{array}$ & Candesartan & C09CA06 & 28 & 28 & $28,28 \%$ \\
\hline & & Irbesartan & C09CA04 & 2 & 2 & $2,02 \%$ \\
\hline \multirow[t]{2}{*}{$\begin{array}{l}\text { Calcium Channel } \\
\text { Blockers }\end{array}$} & $\begin{array}{l}\text { Selective Calcium } \\
\text { Channel Blockers } \\
\text { With Mainly Vascular } \\
\text { Effects }\end{array}$ & Amlodipin & C08CA01 & 37 & 39 & $39,39 \%$ \\
\hline & & Nifedipine & C08CA05 & 0 & 0 & $0,00 \%$ \\
\hline $\begin{array}{l}\text { Digestives, Incl. } \\
\text { Enzymes }\end{array}$ & $\begin{array}{l}\text { Digestives, Incl. } \\
\text { Enzymes }\end{array}$ & Hydrochloric Acid & A09AB03 & 0 & 0 & $0,00 \%$ \\
\hline \multirow[t]{2}{*}{ Diuretics } & $\begin{array}{l}\text { High-Ceiling } \\
\text { Diuretics }\end{array}$ & Furosemide & C03CA01 & 7 & 7 & $7,07 \%$ \\
\hline & $\begin{array}{l}\text { Potassium-Sparing } \\
\text { Agents }\end{array}$ & Spironolactone & C03DA01 & 4 & 4 & $4,04 \%$ \\
\hline Beta Blocking Agents & Beta Blocking Agents & Propranolol & C07AA05 & 0 & 0 & $0,00 \%$ \\
\hline Antihypertensives & $\begin{array}{l}\text { Antiadrenergic } \\
\text { Agents, Centrally } \\
\text { Acting }\end{array}$ & Clonidine & $\mathrm{C} 02 \mathrm{AC} 01$ & 0 & 0 & $0,00 \%$ \\
\hline
\end{tabular}




\section{The health condition of ischemic stroke patients at the time of discharge from hospitalization}

Table IV shows the condition of ischemic stroke patients when they return home alive $(100 \%)$ or dead $(0 \%)$. Based on health research from the Ministry of Health in 2018, stroke is the number one cause of death in Indonesia. The prevalence of stroke in 2013 was 7 out of 1,000 people in Indonesia. This number increased in 2018, to 10.9 per 1,000 population. Data from the Ministry of Health's Health Research and Development Agency in 2014 showed that of all causes of death from various diseases, $21.1 \%$ were caused by stroke [38]. A previous study by Asil (2010) in Japan showed that $63 \%$ of stroke patients were having improved condition and the other 3\% died; while the research of Al Rasyid and Misbach (2015) found that the annual mortality rate of ischemic stroke patients in 28 hospitals in Indonesia was $21.2 \%$. Table IV also showed that male $(9.52 \%)$ was in better condition than female. The results of this study were in accordance with research conducted by Petrea et al. (2009) and Tomita et al. (2015) which stated that the clinical outcome of female ischemic stroke patients was worse than that of men as measured using the NIHSS questionnaire. In the study, it was stated that female ischemic stroke patients tend to have more severe disabilities.

Another study stated the same results, where women had worse outcomes. This was because women have a higher risk of developing various complications such as atrial thromboembolism and many factors influence the clinical outcome between male and female ischemic stroke patients. One of the factors is motor skills. Gross motor skills in men are said to be better than in women. The movements measured on the Barthel Index partially involve gross motor movements, such as walking, going up and downstairs, bathing, and only a few that use fine motor skills such as dressing and dressing (closing buttons). Men with better muscle strength and gross motor skills have better clinical outcomes than women [41,42]. The results of a Spanish study showed that previous atrial fibrillation, previous stroke, cardiovascular complications, and respiratory infections during hospital stay were associated with higher mortality in hospital especially in women, whereas age, dyslipidemia, and respiratory infections were associated with higher mortality. in men. Stroke severity was associated with death in both sexes. Proper prevention and management of this condition are very important to improve the prognosis of patients with ischemic stroke. The severity of the stroke and its infectious respiratory and cardiovascular complications confer an increased risk of in-hospital death in both women and men, especially during the first week of admission [43].

Table 4. Condition of ischemic stroke patients at the time of discharge from hospitalization $(n=42)$

\begin{tabular}{|c|c|c|c|c|}
\hline \multirow{3}{*}{ Characteristics } & \multicolumn{4}{|c|}{ Condition at hospital discharge } \\
\hline & \multicolumn{2}{|c|}{$\begin{array}{c}\text { Alive } \\
(\mathrm{n}=42: 100 \%)\end{array}$} & \multicolumn{2}{|c|}{$\begin{array}{c}\text { Dead } \\
(\mathrm{n}=0: 0 \%)\end{array}$} \\
\hline & $\mathrm{n}$ & $\%$ & $\mathrm{n}$ & $\%$ \\
\hline \multicolumn{5}{|l|}{ Sex } \\
\hline Male & 25 & $59,52 \%$ & & \\
\hline Female & 17 & $40,48 \%$ & & \\
\hline \multicolumn{5}{|l|}{ Age (years) } \\
\hline$<41$ & 0 & $0,00 \%$ & & \\
\hline $41-70$ & 23 & $54,76 \%$ & & \\
\hline$>70$ & 19 & $45,24 \%$ & & \\
\hline \multicolumn{5}{|c|}{ Length of stay (days) } \\
\hline$<5$ & 9 & $21,43 \%$ & & \\
\hline $5-10$ & 28 & $66,67 \%$ & & \\
\hline $11-15$ & 5 & $11,90 \%$ & & \\
\hline
\end{tabular}


Hormones are also thought to influence clinical outcomes. There are differences in sex hormones between men and women, where men are dominated by the sex hormone testosterone, while in women by estrogen. The vasoprotective effect of testosterone leads to better clinical outcomes in men. In women, especially those who have experienced menopause, estrogen levels are very low, so it will have an impact on clinical outcomes [44]. Differences in micro vascularization and neuronal interactions in the brain in men and women are thought to cause different responses to brain damage, thus making the clinical outcome worse in women than in men [41].Patients with improved condition mostly aged $41-70$ years (54.76\%). From the results of the study, it was reported that age also had a significant influence on the clinical outcome of ischemic stroke patients [45]. In this study, there was no significant effect of age on the clinical outcome of ischemic stroke patients, this may be due to the uneven distribution of age in all study subjects, where most of them were dominated by subjects aged $41-70$ years.A total of $66.67 \%$ of patients were treated with a length of stay of 5-10 days and were having improved conditions at discharge. LOS will decrease if clinical outcomes improve and treatment costs are lower than the longer LOS. The clinical pathway if executed properly can reduce LOS and will also directly affect the reduction in treatment costs [46].

\section{Ischemic Stroke Clinic Outcomes}

Clinical outcomes in this study were recurrent stroke, disability, and death. Stroke prognosis can be seen from 6 aspects, namely: death, disease, disability, discomfort, dissatisfaction, and destitution. The six aspects of the prognosis occur in the early phase of stroke or after stroke. To prevent this aspect from getting worse, all patients with acute stroke should be carefully monitored for their general condition, brain function, ECG, oxygen saturation, blood pressure, and body temperature, continuously for 24 hours after a stroke [47]. Stroke disability rates are generally higher than death rates, the ratio between disability and death of stroke patients is four to one [48].

Until now stroke is still a serious health problem. A stroke with an acute attack can cause death in a short time. In addition, stroke is also a major cause of physical and mental disability in productive age and the elderly [49]. Low awareness of stroke risk factors, lack of recognition of stroke symptoms, not yet optimal stroke services, and low adherence to therapy programs for the prevention of recurrent stroke are problems that arise in stroke services in Indonesia. These four things contribute to the increase in the incidence of new strokes, the high mortality rate from stroke, and the high incidence of recurrent strokes in Indonesia [50]. Stroke Engine (2009) stated that $80 \%$ of stroke events can be prevented by treatment and risk factor control through lifestyle modification. Lifestyle modification is one way to prevent recurrent (secondary) strokes.

Table 5. Clinical outcome of hospitalized ischemic stroke patients

\begin{tabular}{|c|c|c|c|c|c|c|}
\hline \multirow{3}{*}{ Characteristics } & \multicolumn{6}{|c|}{ Clinical outcome $(n=42)$} \\
\hline & \multicolumn{2}{|c|}{$\begin{array}{c}\text { Recurrent stroke with } \\
\text { disability } \\
(\mathrm{n}=6: 14,29 \%)\end{array}$} & \multicolumn{2}{|c|}{$\begin{array}{c}\text { Disability } \\
(\mathrm{n}=42: 100 \%)\end{array}$} & \multicolumn{2}{|c|}{$\begin{array}{c}\text { Death } \\
(\mathrm{n}=0: 0 \%)\end{array}$} \\
\hline & $\mathrm{n}$ & $\%$ & $\mathrm{n}$ & $\%$ & $\mathrm{n}$ & $\%$ \\
\hline \multicolumn{7}{|l|}{ Sex } \\
\hline Male & 2 & $33,33 \%$ & 25 & $59,52 \%$ & & - \\
\hline Female & 4 & $66,67 \%$ & 17 & $40,48 \%$ & & \\
\hline \multicolumn{7}{|l|}{ Age (years) } \\
\hline$<41$ & 0 & $0,00 \%$ & 0 & $0,00 \%$ & & \\
\hline $41-70$ & 3 & $50,00 \%$ & 23 & $54,76 \%$ & & \\
\hline$>70$ & 3 & $50,00 \%$ & 19 & $45,24 \%$ & & \\
\hline \multicolumn{7}{|c|}{ Length of stay (days) } \\
\hline$<5$ & 3 & $50,00 \%$ & 9 & $21,43 \%$ & & \\
\hline $5-10$ & 1 & $16,67 \%$ & 28 & $66,67 \%$ & & \\
\hline $11-15$ & 2 & $33,33 \%$ & 5 & $11,90 \%$ & & \\
\hline
\end{tabular}

Statistical test: descriptive 
Table V showed the clinical outcomes of ischemic stroke patients which were $100.00 \%$ experienced disability (mild to severe), 14.29\% experienced recurrent stroke with disability and no patients died. The results of the study stated that patients who had a stroke had a high risk of having another stroke. Repeat stroke attacks ranged from $30 \%-43 \%$ within 5 years. After a transient brain attack, $20 \%$ of patients had a stroke within 90 days and $50 \%$ of them had another stroke within 24-72 hours [51]. The results of the Spanish study showed that the overall hospital mortality rate was $7.13 \%$. Stratifying by the length of hospital stay ( $<7$ days and $\geq 7$ days), it was observed that within the first week, overall mortality was associated with a previous history of stroke, higher stroke severity, and cardiovascular and respiratory complications. After 7 days, the main factor independently associated with overall in-hospital mortality was stroke severity [43]. After the first stroke, the risk of recurrence or death within 5 years was high among the Chinese adult population. Urgent improvement for secondary prevention of stroke in China is needed to reduce this risk [52].The results of a study in London England stated that both mortality and functional dependence 3 months after ischemic stroke decreased by an annual average of about $2.4 \%$ and $1.7 \%$, respectively, during 20002015. Such a reduction was particularly pronounced in strokes with cardio-embolism/CE causes and those aged $\geq 55$ years [53].Stroke is the second leading cause of death and the leading cause of disability worldwide. Stroke incidence is increasing as the population ages. In addition, younger people start to have strokes in low- and middle-income countries.

Ischemic strokes are more common but hemorrhagic strokes are responsible for more deaths and loss of disability-adjusted life-years (DALYs). Incidence and death from stroke differ between countries, geographic regions, and ethnic groups. In particularly high-income countries, improvements in prevention, acute care, and neurorehabilitation have led to a substantial reduction in the burden of stroke over the past 30 years. The opposite is happening in developing countries, the number of stroke sufferers is increasing in line with the changing lifestyle of people, including in Indonesia [54].Stroke is a 10\% cause of death worldwide and the sixth cause of disability. Without proper countermeasures and prevention, stroke could be the fourth leading cause of disability by 2030 [55]. In the United States, stroke is the 3rd leading cause of death. Stroke is a primary neurological problem in the world, while Indonesia is a country with the largest number of stroke sufferers in Asia. The incidence of stroke increases exponentially with age and is 1.25 times greater in men than in women. The trend of patterns of neurological disease, especially central nervous system disorders, has increased due to vascular disorders of the brain, accidents, and the degenerative process of the nervous system [56]. The Indonesian Hospital Association (known as PERSI) in 2009 stated that 65 percent of stroke patients experienced disabilities from various levels, not only those who cannot walk, move, but also other symptoms that indicate a person has had a stroke. By controlling risk factors, the possibility of having a stroke will be reduced so that it will further reduce the stroke rate in Indonesia [38].

\section{Differences in Average Annual Direct Medical Costs in Ischemic Stroke Clinic Outcomes}

Poor management of ischemic stroke will have an impact on the cost of patient care in the hospital. Due to the high cost required for ischemic stroke patients, it is needed to evaluate the disease cost analysis. Cost of Illness can identify and estimate the overall cost of treating a disease in a predetermined population [57]. To optimize hospital management so that hospital financial management is efficient and optimal, as well as to carry out quality control, cost control, and access, the cost of care is calculated based on unit cost calculations owned by hospitals [58]. Stroke is not only a major challenge for patients and their families but also a major financial burden on the health care system. High direct costs are incurred by expensive acute care and rehabilitation [59].Clinical outcomes are the main goal in the management of any ischemic stroke. In this study, the clinical outcome parameters assessed were recurrent stroke and disability.Table VI shows that the incidence of recurrent stroke does not affect the outpatient or inpatient costs. This is because the condition of the patient at the time of admission to inpatient care is in severe health condition (recurrent stroke incidence) and does not require high treatment costs. The opposite condition can also occur when they have a good clinical outcome (recurrent stroke incidence) at the time of admission but requires a higher cost to treat the patient's recurrent stroke. 
The average value of outpatient costs for patients who do not have recurrent strokes or disability or recurrent strokes and disabilities has a greater value than patients with recurrent strokes or disability or recurrent strokes and disability because these high costs are used to finance patient therapy so that the patient was not exposed to the above disease. Factors that affect direct medical costs are stroke severity, type of stroke and comorbid factors that are more than one, and alcohol use [60]. About $25 \%$ of people who successfully overcome their first stroke will have recurrent strokes within five years [61]. According to the National Stroke Association (2006), the incidence of recurrent stroke can occur 30 days after the first attack, which is $5 \%-14 \%$, and repeated attacks 5 years after the first attack are $25 \%-40 \%$. The risk of recurrent stroke will decrease if the patient undergoes regular treatment and prevention of stroke risk factors [62].Table VI showed the outpatient and inpatient costs in the different ward classes. There is no significant difference in direct medical costs for outpatient and inpatient based on the incidence of disability. The incidence of disability does not affect the outpatient or inpatient costs. This was because the patient's condition at the time of admission to inpatient care was severe health condition (disability incidence) and did not require high treatment costs. The opposite condition could also occur when they were in good clinical outcome (disability incidence) at the time of admission but requires a higher cost to treat the incidence of patient disability.

Disability is an increasingly large component of the burden of stroke therefore a higher cost is required. With the global population increasing with age, the demands on healthcare services to treat disabilities are also increasing. Policymakers, in this case, the government, are obliged to provide the necessary facilities and require regular detailed health reporting of the population [63].Research from Damaerschalk et al. (2010) stated that the cost and length of stay in hospital (LOS) were related to age. Predictive factors that significantly affect LOS are diabetes mellitus, atrial fibrillation, recurrence, and stroke subtype [64]. Similar results from another study stated that someone who has had a stroke needs to be aware of the occurrence of recurrent strokes because it will not only increase morbidity and mortality but can also lead to high costs of care and treatment [65]. Research reported that the impact of stroke problems in addition to causing disability and death can also reduce productivity levels if the sufferer is of productive age. From a social perspective, stroke sufferers will experience mental depression, feel inferior, and shut themselves off from the community so that it will increase the psychological burden for the stroke sufferer, while the economic impact is the large cost for treatment of recurrent strokes and rehabilitation [66]. 
International Journal of Health and Pharmaceutical

Table 6. The differences of annual direct medical cost on ischemic stroke clinical outcome $(n=42)$

\begin{tabular}{|c|c|c|c|c|c|c|c|c|c|c|c|c|c|c|c|}
\hline \multirow{2}{*}{\multicolumn{2}{|c|}{ Outcome }} & \multirow{2}{*}{$\mathrm{N}$} & \multirow{2}{*}{$\begin{array}{c}\begin{array}{c}\text { Hospital } \\
\text { ownership }\end{array} \\
\begin{array}{c}\text { Private } \\
\text { hospital }\end{array} \\
\end{array}$} & \multirow{2}{*}{$\begin{array}{l}\begin{array}{r}\text { Type of } \\
\text { hospital }\end{array} \\
\text { Type B }\end{array}$} & \multicolumn{3}{|c|}{ Type of ward } & \multicolumn{4}{|c|}{ Outpatient cost } & \multicolumn{4}{|c|}{ Inpatient cost } \\
\hline & & & & & Class I & Class II & $\begin{array}{c}\text { Class } \\
\text { III }\end{array}$ & & $\operatorname{an} \pm$ & & p-value & & $n \pm$ & & p-value \\
\hline \multirow{2}{*}{$\begin{array}{l}\text { Recurrent } \\
\text { stroke }\end{array}$} & Yes & 6 & 6 & 6 & 3 & 0 & 3 & 1.021 .518 & \pm & 530.803 & \multirow{2}{*}{0.652} & 2.940 .317 & \pm & 709.530 & \multirow{2}{*}{0.227} \\
\hline & No & 36 & 36 & 36 & 13 & 7 & 16 & 1.392 .251 & \pm & 1.169 .096 & & 3.971 .486 & \pm & 2.921 .315 & \\
\hline \multirow{2}{*}{ Disability } & Yes & 42 & 42 & 42 & 16 & 7 & 19 & 1.339 .289 & \pm & 1.103 .797 & & 3.824 .176 & \pm & 1.979 .537 & \\
\hline & No & 0 & 0 & 0 & 0 & 0 & 0 & & \pm & & & & \pm & & \\
\hline \multirow{2}{*}{$\begin{array}{l}\text { Recurrent } \\
\text { stroke and } \\
\text { disability }\end{array}$} & Yes & 6 & 6 & 6 & 3 & 0 & 3 & 1.021 .518 & \pm & 530.803 & \multirow{2}{*}{0.652} & 2.940 .317 & \pm & 709.530 & \multirow{2}{*}{0.227} \\
\hline & No & 36 & 36 & 36 & 13 & 7 & 16 & 1.392 .251 & \pm & 1.169 .096 & & 3.971 .486 & \pm & 2.921 .315 & \\
\hline
\end{tabular}

Descriptive Statistic 
Table VI showed that there was no difference in the difference in direct medical costs for outpatient and inpatient care based on recurrent stroke and disability. The incidence of recurrent stroke and disability did not affect the outpatient or inpatient costs. This was because the patient's condition at the time of admission to inpatient care differs in the severity of ischemic stroke. The condition of patients who are in poor severity (bad/poor clinical outcome) is treated for only a short time so it requires a small fee. The opposite condition can also occur in conditions of good clinical outcome (recurrent stroke incidence and disability) but requires a higher cost to treat recurrent stroke events and patient disability and requires a longer stay.

Outpatient and inpatient costs in this study showed the lowest cost value in the clinical outcome of recurrent stroke with disability compared to recurrent stroke alone or disability alone.Epidemiological data states that the risk for recurrence of stroke is $30 \%$ and the population who has had a stroke has a 9 times chance of having a recurrence compared to the normal population [67]. It is estimated that $25 \%$ of people who recover from their first stroke will have a recurrent stroke within 1- 5 years [68].Secondary prevention in the form of giving antihypertensive therapy and being obedient in using/taking antihypertensive therapy has the effect of reducing the incidence of recurrent stroke. Factors that influence the incidence of recurrent stroke are as follow: not using antihypertensive therapy, systolic blood pressure $\geq 140 \mathrm{mmHg}$, HDL levels $<40 \mathrm{mg} / \mathrm{dl}$, and inactivity. Inactive patients have a risk of having a recurrent stroke by 2,365 times compared to patients who do routine activities [26]. Physical activity has benefits on stroke risk factors. However, patients who have had a stroke may have a disability that causes difficulty in activities. One study showed that aerobic exercise improves cardiovascular health, mobility, balance, and endurance after a stroke [69].

\section{CONCLUSION}

The results showed that the largest sociodemographic factors of stroke patients were at the age of 41-70 years $(54.76 \%)$, male $(59.52 \%), 5-10$ days of hospitalization $(66.60 \%)$, comorbid of hypertension $(88.10 \%)$, complications of urinary tract infections $(19.05 \%)$, Charlson Comorbidity Index 3-5 (85.71\%), conditions at hospital admission with hemiparesis (83.72\%), and antiplatelet pharmacological therapy $(90.48 \%)$. The clinical outcome of ischemic stroke in the form of recurrent stroke was mostly female (66.60\%), age 41-70 years and > 70 years (@50.00\%), and length of hospitalization $<5$ days $(50.00 \%)$. The clinical outcome of ischemic stroke in the form of disability is mostly found in males $(59.52 \% \%)$, age $41-70$ years old $(54.76 \%)$, and 5-10 days of hospitalization $(66.67 \%)$.

Annual direct medical costs on the clinical outcome of ischemic stroke in the incidence of recurrent stroke occurred in ward class I and III, outpatient cost of Rp. 1.021.518 \pm 530.803 and inpatient cost of Rp. 2.940.317 \pm 709.530 . Annual direct medical costs on the clinical outcome of ischemic stroke in the incidence of disability occurred in the ward class I, II, and III, outpatient cost of Rp. 1.339.289 \pm 1.103 .797 and inpatient cost of Rp. 3.824.176 \pm 1.979 .537 . Clinical outcomes of 42 ischemic stroke patients with 48 clinical outcomes were recurrent stroke and disability of $14.29 \%(\mathrm{n}=$ 6), $100 \%$ disability $(n=42)$, and $0.00 \%$ death $(n=0)$. The incidence of recurrent stroke and disability did not affect the direct medical costs per year, both outpatient and inpatient costs. This was because the severity of the patient's condition at the time of hospital admission was not considered in this study. The results of this study are used in determining health policies, health insurance, and sources of pharmacoeconomic data for ischemic stroke.

\section{ACKNOWLEDGEMENTS}

We would like to thank LPPM Universitas Muhammadiyah Semarang which has funded this research and also the research team of lecturers and students. 


\section{REFERENCES}

[1] Omote Y, Deguchi K, Tian F, et al. Clinical and pathological improvement in stroke-prone spontaneous hypertensive rats related to the pleiotropic effect of cilostazol. Stroke J Cereb Circ. 2012;43(6):16391646. doi:10.1161/STROKEAHA.111.643098 Organization WH. World Health Statistics 2015. World Health Organization; 2015.

[2] Chang KC, Tseng MC, Weng HH, Lin YH, Liou CW, Tan TY. Prediction of Length of Stay of FirstEver Ischemic Stroke. Stroke. 2002;33(11):2670-2674. doi:10.1161/01.STR.0000034396.68980.39

[3] Purbaningsih S, Wahyono D, Suparniati E. Cost of illness pasien stroke. J Manag Pharm Pract. 2015;5(2):95-103.

[4] Dinata CA, Safrita YS, Sastri S. Gambaran Faktor Risiko dan Tipe Stroke pada Pasien Rawat Inap di Bagian Penyakit Dalam RSUD Kabupaten Solok Selatan Periode 1 Januari 2010-31 Juni 2012. J Kesehat Andalas. 2013;2(2):57-61.

[5] Jiang S, Fei A, Peng Y, et al. Predictors of Outcome and Hemorrhage in Patients Undergoing Endovascular Therapy with Solitaire Stent for Acute Ischemic Stroke. PLoS ONE. 2015;10(12). doi:10.1371/journal.pone.0144452

[6] Segel JE. Cost-of-illness studies - a primer. RTI-UNC Cent Excell Health Promot Econ. Published online December 26, 2006:1-39.

[7] Permenkes. PERMENKES Nomor 76 Tahun 2016 Tentang Pedoman INACBG Dalam Pelaksanaan JKN. Published online September 30, 2016.

[8] Dipiro C, Wells B, Schwinghammer T, DiPiro J. Pharmacotherapy Handbook, 9/E. McGraw-Hill Education; 2014.

[9] Nemeroff CB, Clermont GP. Heartache and heartbreak - the link between depression and cardiovascular disease. Nat Rev Cardiol. 2012;9(9):526-539. doi:10.1038/nrcardio.2012.91

[10] Powers WJ, Rabinstein AA, Ackerson T, et al. Guidelines for the Early Management of Patients With Acute Ischemic Stroke: 2019 Update to the 2018 Guidelines for the Early Management of Acute Ischemic Stroke: A Guideline for Healthcare Professionals From the American Heart Association/American Stroke Association. Stroke. 2019;50(12). doi:10.1161/STR.0000000000000211

[11] Firmansyah F, Andayani TM, Pinzon RT. Analisis biaya penyakit stroke iskemik. J Manag Pharm Pract. 2016;6(1):27-34. doi:10.22146/jmpf.235

[12] Nordin, Sulung, Aljunid. (PDF) Direct medical cost of stroke: Findings from a tertiary hospital in Malaysia. $\quad$ 2012. Published Accessed 2020. https://www.researchgate.net/publication/239525077_Direct_medical_cost_of_stroke_Findings_from_a_ tertiary_hospital_in_Malaysia

[13] Chow WL, Tin AS, Meyyappan A. Factors Influencing Costs of Inpatient Ischaemic Stroke Care in Singapore. Proc Singap Healthc. 2010;19(4):283-291. doi:10.1177/201010581001900402

[14] Pinzon R, Asanti L. AWAS STROKE! Pengertian, Gejala, Tindakan, Perawatan dan Pencegahan. Penerbit Andi; 2010.

[15] Elisabeth F, Lesmana D, Destanul A. Dominant Factor Analysis of Hypertension in Pre-Elderly Men and Women in Puskesmas Rangkapanjaya, Depok City, 2016. In: Atlantis Press; 2016. doi:10.2991/phico16.2017.12

[16] Japardi I. Patofisiologi Stroke Infark Akibat Tromboemboli. Published 2002. Accessed March 28, 2020. http://repository.usu.ac.id/handle/123456789/1982

[17] Sulastomo. Sulastomo: Jaminan Sosial Jalan Menuju Mandiri. KOMPAS.com. Published 2014. Accessed $\begin{array}{lll}\text { March } & 2020 .\end{array}$ https://nasional.kompas.com/read/2014/06/26/1716487/Sulastomo.Jaminan.Sosial.Jalan.Menuju.Mandiri

[18] Dwidayati A, Andayani TM, Wiedyaningsih C. Analisis Kesesuaian Biaya Riil Terhadap Tarif INACBGS Pada Pengobatan Stroke Non Hemoragik Pasien JKN Rawat Inap RSUD Dr. Soehadi Prijonegoro Sragen Tahun 2015. J Farm Indones. 2016;13(2):139-149. doi:10.31001/jfi.v13i2.284

[19] Always, Cole. Buku Kedokteran: Buku Esensial Stroke untuk Layanan Primer. Published 2012. Accessed March 23, 2020. https://www.egcmedbooks.com/buku/detail/918/esensial-stroke-untuklayanan-primer 
[20] Sulastriati, Mahyudin, Haskas. hubungan Pengetahuan Dan Sikap Dengan Perilaku Pasien Hipertensi Terhadap Pencegahan Stroke Di Rumah Sakit Umum Daerah Daya Kota Makassar. Published 2013. Accessed March 24, 2020. http://ejournal.stikesnh.ac.id/index.php/jikd/article/view/468

[21] Guo M, Ying D, Cong-Geng M. Profile and 1-Year Outcome of Ischemic Stroke in East China: Nanjing First Hospital Stroke Registry - ScienceDirect. Published 2015. Accessed March 29, 2020. https://www.sciencedirect.com/science/article/abs/pii/S1052305715004760

[22] Budiarti I. Infeksi Saluran Kemih Bisa Jadi Pertanda Serangan Stroke, Begini Penjelasan Penelitian. Tribun Bali. Published 2019. Accessed March 28, 2020. https://bali.tribunnews.com/2019/07/14/infeksisaluran-kemih-bisa-jadi-pertanda-serangan-stroke-begini-penjelasan-penelitian

[23] Goldstein LB, Samsa GP, Matchar DB, Horner RD. Charlson Index Comorbidity Adjustment for Ischemic Stroke Outcome Studies. Stroke. 2004;35(8):1941-1945. doi:10.1161/01.STR.0000135225.80898.1c

[24] Sul B, Kim JS, Hong BY, et al. The Prognosis and Recovery of Aphasia Related to Stroke Lesion. Ann Rehabil Med. 2016;40(5):786-793. doi:10.5535/arm.2016.40.5.786

[25] Karuniawati H, Ikawati Z, Gofir A. Pengaruh Pencegahan Sekunder Terhadap Kejadian Stroke Berulang Pada Pasien Stroke Iskemik Di Rsud. Dr. Moewardi Di Surakarta. Published online 2015. Accessed April 4, 2020. http://etd.repository.ugm.ac.id/home/detail_pencarian/80783

[26] Damanik V. Guideline Stroke Tahun 2011 Pokdi Stroke Perhimpunan Dokter Spesialis Saraf Indonesia (Perdossi) Bagian Ilmu Penyakit Saraf Rsud Arifin Achmad Pekanbaru. Published online 2011. Accessed March 2019. https://www.academia.edu/31321416/GUIDELINE_STROKE_TAHUN_2011_POKDI_STROKE_PER HIMPUNAN_DOKTER_SPESIALIS_SARAF_INDONESIA_PERDOSSI_BAGIAN_ILMU_PENYAK IT_SARAF_RSUD_ARIFIN_ACHMAD_PEKANBARU

[27] Husni A, Laksmawati. Faktor Yang Mempengaruhi Stroke Non Hemoragik Ulang., 2001 ; 36(3) :. Media Med Indones. 2001;36(3):133-144.

[28] Nildawati, Suharyo H, Widiastuti S. Beberapa Faktor Risiko Yang Berpengaruh Terhadap Kejadian Stroke Non Hemoragik (Studi Kasus Di Stroke Center Rumah Sakit Khusus Daerah Propinsi Sulawesi Selatan). Published 2014. Accessed April 5, 2020. http://journal.uinalauddin.ac.id/index.php/kesehatan/article/view/59

[29] Amarenco P, Goldstein LB, Szarek M, et al. Effects of Intense Low-Density Lipoprotein Cholesterol Reduction in Patients With Stroke or Transient Ischemic Attack: The Stroke Prevention by Aggressive Reduction in Cholesterol Levels (SPARCL) Trial. Stroke. 2007;38(12):3198-3204. doi:10.1161/STROKEAHA.107.493106

[30] Unger T, Borghi C, Charchar F, et al. International Society of Hypertension Global Hypertension Practice Guidelines. Published online 2020:24.

[31] Aman A, Soewondo P, Arsana PM, Wismandari. Panduan Pengelolaan Dislipidemia di Indonesia 2019. Published 2019. Accessed June 8, 2020. https://pbperkeni.or.id/wp-content/uploads/2019/12/Panduanpengelolaan-dislipidemia-2019.pdf

[32] Wells BG, DiPiro JT. Pharmacotherapy-Handbook-9th-Edition. McGraw Hill; 2015. Accessed November 15, 2019. https://www.academia.edu/36931722/pharmacotherapy-handbook-9th-edition.pdf

[33] Gofir A. Manajemen Stroke Evidence Based Medicine. Kedua ed. ResearchGate. Published 2011. $\begin{array}{lll}\text { Accessed November } & 15, & 2019 .\end{array}$ http://opac.lib.ugm.ac.id/index.php?mod=book_detail\&sub=BookDetail\&act=view\&typ=htmlext\&buku_ id $=675675$ \&obyek_id $=1$

[34] Furie KL, Kasner SE, Adams RJ, et al. Guidelines for the prevention of stroke in patients with stroke or transient ischemic attack: a guideline for healthcare professionals from the american heart association/american stroke association. Stroke. 2011;42(1):227-276. doi:10.1161/STR.0b013e3181f7d043

[35] Jauch JL, Saver JL. Guidelines For The Early Management Of Patients With Acute Ischemic Stroke: A Guideline For Heathcare Profesionals From The American Heart Associatio/American Stroke Association. Stroke AHA J. 2013;44:30-87. 
International Journal of Health and Pharmaceutical

[36] Kernan WN, Ovbiagele B, Black HR, et al. Guidelines for the prevention of stroke in patients with stroke and transient ischemic attack: a guideline for healthcare professionals from the American Heart Association/American Stroke Association. Stroke. 2014;45(7):2160-2236. doi:10.1161/STR.0000000000000024

[37] Bustami M. Stroke Disebut Penyebab Kematian Nomor Satu di Indonesia. Republika Online. Published October 25, 2019. Accessed April 11, 2020. https://republika.co.id/share/pzxqqk284

[38] Petrea R, Beiser A, Seshadri S, Petrea Kelly-Hayes M, Kase C, Wolf P. Gender Differences in Stroke Incidence and Poststroke Disability in the Framingham Heart Study | Stroke. Published 2009. Accessed April 12, 2020. https://www.ahajournals.org/doi/full/10.1161/strokeaha.108.542894

[39] Tomita H, Hagii J, Metoki N, et al. Impact of Sex Difference on Severity and Functional Outcome in Patients with Cardioembolic Stroke. J Stroke Cerebrovasc Dis. 2015;24(11):2613-2618. doi:10.1016/j.jstrokecerebrovasdis.2015.07.016

[40] Ikeda T, Aoyagi O. Relationships between Gender Difference in Motor Performance and Age, Movement Skills and Physical Fitness among 3- to 6-year-old Japanese Children based on Effect Size Calculated by Meta-analysis. Sch Health. 2009;5:9-23. doi:10.20812/jash.SH-2009_031

[41] Smith JL. Activities for Fine Motor Skills Development. Teacher Created Resources; 2003.

[42] Kortazar-Zubizarreta I, Pinedo-Brochado A, Azkune-Calle I, Aguirre-Larracoechea U, GomezBeldarrain M, Garcia-Monco JC. Predictors of in-hospital mortality after ischemic stroke: A prospective, single-center study. Health Sci Rep. 2019;2(4):e110. doi:10.1002/hsr2.110

[43] Hess R. Estrogen in the adult male reproductive tract: A review | SpringerLink. Published 2003. Accessed April 12, 2020. https://link.springer.com/article/10.1186/1477-7827-1-52

[44] Corso G, Bottacchi E, Tosi P, et al. Outcome Predictors in First-Ever Ischemic Stroke Patients: A Population-Based Study. International Scholarly Research Notices. doi:https://doi.org/10.1155/2014/904647

[45] Cannon C, Hand M, Bahr R, Boden W. Critical pathways for management of patients with acute coronary syndromes: An assessment by the National Heart Attack Alert Program. Am Heart J. 2002;143(5):777-789. doi:10.1067/mhj.2002.120260

[46] Asmedi A, Lamsuddin R. Prognosis Stroke. Dalam : Manajemen Stroke Mutakhir. h. 89-94. Suplemen BKM XIV.1998.

[47] Lumbantobing SM. Demensia. LIPI; 1996.

[48] Gorelick PB. Stroke Prevention Arch Neuro. Published online 1995.

[49] Kemenkes RI. Keputusan Menteri Kesehatan Nomor HK.01.07/MENKES/ 659/2017 Tentang Formularium Nasional. Published online b 2017.

[50] Erpinz. Mengendalikan Tekanan Darah Pasca Stroke. Published online 2015. http://www.strokebethesda.com

[51] Chen Y, Wright N, Guo Y, et al. Mortality and recurrent vascular events after first incident stroke: a 9year community-based study of $0 \cdot 5$ million Chinese adults. Lancet Glob Health. 2020;8(4):e580-e590. doi:10.1016/S2214-109X(20)30069-3

[52] Wafa HA, Wolfe CDA, Bhalla A, Wang Y. Long-term trends in death and dependence after ischaemic strokes: A retrospective cohort study using the South London Stroke Register (SLSR). Meisinger C, ed. PLOS Med. 2020;17(3):e1003048. doi:10.1371/journal.pmed.1003048

[53] Katan M, Luft A. Global Burden of Stroke. Semin Neurol. 2018;38(02):208-211. doi:10.1055/s-00381649503

[54] Arofah AN. Penatalaksanaan Stroke Trombotik: Peluang Peningkatan Prognosis Pasien. Saintika Med J Ilmu Kesehat Dan Kedokt Kel. 2012;7(1). doi:10.22219/sm.v7i1.1088

[55] Lefrina. Waspadai Stroke Infark yang Mengancam Usia Muda. Alodokter. Published March 31, 2018. Accessed April 11, 2020. https:/www.alodokter.com/waspadai-stroke-infark-yang-mengancam-usiamuda

[56] Segel JE. Cost-of-Illness Studies-A Primer. Published online 2006:40.

[57] Kemenkes RI. Peraturan Menteri Kesehatan Republik Indonesia Nomor 71 Tahun 2013 Tentang Pelayanan Kesehatan Pada Jaminan Kesehatan Nasional. Kementrian Kesehatan Republik Indonesia, Jakarta. Published online b 2014. 
[58] Snozzi P, Blank PR, Szucs TD. Stroke in Switzerland: Social Determinants of Treatment Access and Cost of Illness. J Stroke Cerebrovasc Dis. 2014;23(5):926-932. doi:10.1016/j.jstrokecerebrovasdis.2013.07.042

[59] Suzuki K, Suzuki K, Izumi M, Sakamoto T, Hayashi M. Blood Pressure and Total Cholesterol Level Are Critical Risks Especially for Hemorrhagic Stroke in Akita, Japan. Cerebrovasc Dis. 2011;31(1):100-106. doi:10.1159/000321506

[60] Siswanto yuliaji. beberapa faktor yang mempengaruhi kejadian stroke berulang. Published online 2005.

[61] Sacco RL, Sacco M, Chair. Guidelines for Prevention of Stroke in Patients With Ischemic Stroke or Transient Ischemic Attack | Stroke. Published 2006. Accessed April 13, 2020. https://www.ahajournals.org/doi/full/10.1161/01.STR.0000199147.30016.74

[62] Vos T, Lim SS, Abbafati C, et al. Global burden of 369 diseases and injuries in 204 countries and territories, 1990-2019: a systematic analysis for the Global Burden of Disease Study 2019. The Lancet. 2020;396(10258):1204-1222. doi:10.1016/S0140-6736(20)30925-9

[63] Huang YC, Hu CJ, Lee TH, et al. The Impact Factors on the Cost and Length of Stay among Acute Ischemic Stroke. J Stroke Cerebrovasc Dis.

2013;22(7):e152-e158. doi:10.1016/j.jstrokecerebrovasdis.2012.10.014

[64] Martiani A, Pratiwi N. Hubungan stres, pola makan, kepatuhan minum obat terhadap terjadinya stroke berulang di rumah sakit wilayah kabupaten Pekalongan tahun 2012. Published online 2014.

[65] Penado S, Cano M, Acha O, Hernández JL, Riancho JA. Atrial fibrillation as a risk factor for stroke recurrence. Am J Med. 2003;114(3):206-210. doi:10.1016/S0002-9343(02)01479-1

[66] Lamsudin R, Basyiruddin, Suroto, Alfa AY, Misbach J. Guideline Stroke Pokdi Stroke Perhimpunan Dokter Spesialis Saraf Indonesia (PERDOSSI). PERDOSSI. Published online 2011.

[67] Bostom AG, Selhub J, Jacques PF, Rosenberg IH. Power Shortage: Clinical Trials Testing the "Homocysteine Hypothesis" against a Background of Folic Acid-Fortified Cereal Grain Flour. Ann Intern Med. 2001;135(2):133-137. doi:10.7326/0003-4819-135-2-200107170-00014

[68] Lambert M. AHA/ASA Guidelines on Prevention of Recurrent Stroke. 2011;83(8):5. 